\section{A pericentric inversion duplication of the subcentromeric region of chromosome $12 q$}

The proband, a 1 year old girl, was referred because of dysmorphic features and developmental delay. There was no family history of congenital abnormalities and the mother had received no drugs during her pregnancy.

The mother was 25 and the father 26 years old at the time of the birth. The pregnancy was normal and the birth uncomplicated. She learnt to sit at 3 months and to crawl at 5 months. She now walks unaided, yet she does not talk or make any sounds. She appears to understand what is said to her. The only abnormalities are a large protruding tongue and epicanthic folds.

Cultured peripheral lymphocytes were used for chromosomal analysis with GTG and R banding. All 15 cells examined showed an elongation of the short arm of one of the chromosomes 12 . This was evaluated in the $\mathrm{G}$ banded slides as an inverted duplication in the short arm of the immediate subcentromeric region of the long arm: $\operatorname{dup}(12 p)(q 11 \rightarrow q 12)$ (figure). The chromosomes of both parents were normal.

A P Albert, Jennifer Holdsworth, ANd Carol Massyn

Department of Cytogenetics, Eastern Province Blood Transfusion Service, Port Elizabeth 6000, South Africa.

Correspondence and requests for reprints to Dr A P Albert, Department of Cytogenetics, Eastern Province Blood Transfusion Service, Buckingham Road, Port Elizabeth 6000 , South Africa.
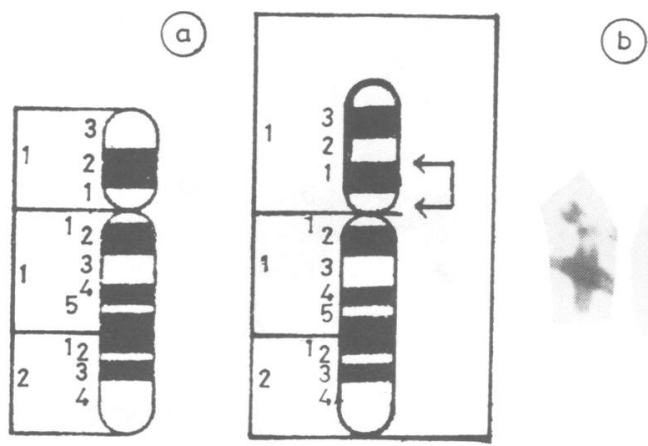

12

der (12)

FIGURE (a) Diagram of normal and abnormal chromosomes 12. (b) $G$ banded partial karyotype showing the inversion duplication.

\section{Partial trisomy $1 \mathrm{q} 25 \rightarrow \mathrm{qter}$}

A male infant, birth weight $2.78 \mathrm{~kg}$, gestation 38 weeks, with chromosomally normal parents, had a karyotype $46, X Y,-17,+\operatorname{der}(17), t(1 ; 17)(q 25 ; p 13)$ (figure). Clinical findings included moderate enlargement of the cranium with a prominent forehead naevus, long philtrum, thin upper lip, very small palpebral fissures, irregular gums, large asymmetrical ears, undescended testes, hypoplastic scrotum, bifid right thumb, syndactyly of the second and third toes of the left foot, and rockerbottom feet. The infant showed cardiorespiratory distress and died at 10 hours. Necropsy revealed a ventricular septal defect but the brain was well developed and the optic nerves and tracts, olfactory nerves, corpus callosum, and septum pellucidum all appeared normal.

E JANET TAWN*, M B R Roberts $\dagger$, R G Ghazala $\ddagger$, AND Elizabeth M T Pyta*

*Cytogenetics Laboratory, Medical Department, British Nuclear Fuels plc, Seascale, Cumbria CA20 1PG, and Departments of Paediatricst and Pathology $\neq$,

West Cumberland Hospital, Hensingham, Whitehaven, Cumbria CA28 8JG.

Correspondence and requests for reprints to Mrs E J Tawn, Cytogenetics Laboratory, Medical Department, British Nuclear Fuels plc, Seascale, Cumbria CA20 1PG.

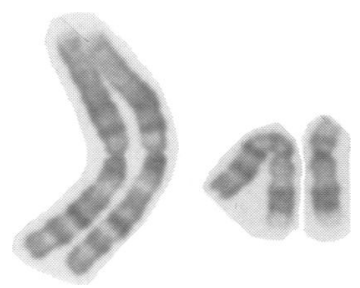

FIGURE Partial karyotype of chromosomes 1 and 17.

Received for publication 21 June 1985.

Revised version accepted for publication 22 August 1985.

\section{Secondary amenorrhoea and $47, X X, i(X q)$ karyotype}

A 25 year old female underwent normal pubertal development with menarche at $\mathbf{1 0}$ years of age. Her menses were regular until 21 years of age when they became scanty and irregular. She received cyclic hormonal therapy with withdrawal bleeding, but for 18 months before being seen

Received for publication 15 October 1985.

Accepted for publication 18 October 1985. 